\title{
Ekonomik, Finansal ve Politik Risk ile Büyüme Arasındaki Nedensellik Illişkisi: Türkiye Örneği
}

\author{
Causality Relationship Between Economic, Financial, Political Risk and \\ Growth: The Case of Turkey
}

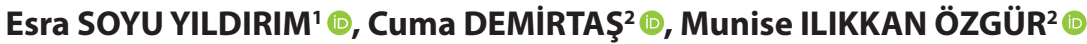

\section{öz}

Bu çalışmanın amacı, Türkiye'nin ekonomik, finansal ve politik risk oranları ile büyüme arasındaki nedensellik ilişkisini incelemektir. Çalışmada 2000:01- 2020:06 döneminde söz konusu risk oranları ile büyüme arasındaki ilişkiyi incelemek için Toda-Yamamoto nedensellik testi, Hatemi-J tarafından geliştirilen Bootstrap Toda-Yamamoto nedensellik testi ve zamanla değişen simetrik ve asimetrik nedensellik testleri kullanılmıştır. Elde edilen bulgular şu şekildedir: (i) Toda-Yamamoto nedensellik testine göre; finansal riskten büyümeye, ekonomik riskten finansal riske ve ekonomik riskten politik riske doğru nedensellik ilişkisi bulunmaktadır. (ii) Bootstrap Toda-Yamamoto nedensellik testine göre finansal riskten büyümeye doğru nedensellik ilişkisi vardır. Bootstrap Toda-Yamamoto asimetrik nedensellik testine göre; finansal riskteki pozitif şok büyümede pozitif şoka, finansal riskteki negatif şok büyümede negatif şoka ve politik riskteki negatif şok ise büyümede pozitif şoka yol açmaktadır. (iii) Zamanla değişen simetrik nedensellik testine göre nedensellik ilişkisinin olduğu dönemler; ekonomik riskten büyümeye doğru, finansal riskten büyümeye doğru ve politik riskten büyümeye doğru tespit edilmiştir. Zamanla değişen asimetrik nedensellik testine göre nedensellik ilişkisinin olduğu dönemler; ekonomik riskteki negatif şokun büyümedeki pozitif şoka ekonomik riskteki pozitif şokun büyümedeki negatif şoka; finansal riskteki negatif şokun büyümedeki pozitif şoka, finansal riskteki pozitif şokun büyümedeki negatif şoka etkilerini göstermektedir. Ancak söz konusu dönemde sadece politik riskteki pozitif şokun büyümede negatif şoka neden olduğu dönem görülmektedir.

Anahtar Kelimeler: Ekonomik risk, Finansal risk, Politik risk, Ekonomik büyüme, Nedensellik analizi

Jel Sınıflaması: F34, E43, G32

DOI: 10.26650/JEPR1016857

${ }^{1}$ Aksaray Üniversitesi, Sosyal Bilimler Meslek Yüksek Okulu, Aksaray, Türkiye

${ }^{2}$ Aksaray Üniversitesi, İktisadi ve İdari Bilimler Fakültesi İktisat Bölümü, Aksaray , Türkiye

ORCID: E.S.Y. 0000-0003-1614-0967;

C.D. 0000-0002-1475-5530;

M.I.Ö. 0000-0002-8711-3264

\section{Sorumlu yazar/Corresponding author:} Esra SOYU YILDIRIM,

Aksaray Üniversitesi, Sosyal Bilimler Meslek Yüksek Okulu, Aksaray, Türkiye

E-posta/E-mail:

esrasoyu@gmail.com

Başvuru/Submitted: 31.10 .2021

Revizyon Talebi/Revision Requested: 13.12.2021

Son Revizyon/Last Revision Received: 29.12.2021

Kabul/Accepted: 30.12 .2021

Atıf/Citation: Soyu Yildirim, E., Demirtas, C., \& İlikkan Ozgur, M. (2022). Ekonomik, finansal ve politik risk ile büyüme arasındaki nedensellik ilișkisi: Türkiye örneği.. İktisat Politikası Araştırmaları Dergisi - Journal of Economic Policy Researches, 9(1), 165-186. https://doi.org/10.26650/JEPR1016857

This work is licensed under Creative Commons Attribution-NonCommercial 4.0 International License 


\begin{abstract}
This study aims to examine the causality relationship between Turkey's economic, financial and political risk ratios and growth. Toda-Yamamoto causality, Bootstrap Toda-Yamamoto causality, and time-varying symmetric and asymmetric causality tests were used to examine the relationship between the risk ratios and growth between 2000- 2020. The findings show that (i) The Toda-Yamamoto causality test shows a causal relationship between financial risk and growth, economic risk and financial risk, and economic risk and political risk. (ii) The Bootstrap Toda-Yamamoto causality test revealed a causal relationship between financial risk and growth. The Bootstrap Toda-Yamamoto, asymmetric causality test, showed that a positive shock in financial risk causes a positive shock in growth, a negative shock in financial risk causes a negative shock in growth, and a negative shock in political risk causes a positive shock in growth. (iii) The time-varying relationship symmetric causality tests allowed for detecting causality between economic risk and growth, financial risk and growth, and political risk and growth. The time-varying relationship asymmetric causality tests revealed that a negative shock in economic risk caused a positive shock in growth; a positive shock in economic risk caused a negative shock in growth; a negative shock in financial risk caused a positive shock in growth and demonstrated the effects of the positive shock in financial risk as a negative shock in growth. However, a negative shock in growth was only observed when there was a positive shock in political risk.
\end{abstract}

Keywords: Economic risk, Financial risk, Political risk, Economic growth, Causality analysis

Jel Classification: F34, E43, G32

\title{
EXTENDED ABSTRACT
}

Economic growth continues to be one of the areas that researchers focus on because small increases in the growth rates of countries can create significant effects that can change their welfare and living standards. Questions such as "why are some countries developing more rapidly than others?", "Why do different countries develop differently?" has always been on the agenda of economists since different national growth performances have caused significant differences in indicators such as per capita income and living standards (Acemoğlu, 2012).

Das and Loxley (2015), Berber and Artan (2004), and Barro (1995) reveal the relationship between inflation and growth; Kutlu and Yurttagüler (2016) and Pattillo et al. (2011) indicate a relationship between foreign debt and economic growth; Kenourgios and Samitas (2007) and Dudian and Popa (2013) identified a relationship between credit and economic growth; Caporale et al., (2009), Calderon and Liu (2003), Christopoulos and Tsionas (2004), and Soytaş and Küçükkaya (2011) examine the relationship between financial development and economic growth. In addition, studies such as Feng (2001), Chen and Feng (1996), Tang and Abosedra (2014), Çela and Hysa (2021), and Pasha (2020) have investigated the relationship between political indicators and growth. These studies narrowly analyze the effect of economic, financial, and political variables on economic growth based on a single subcomponent. However, considering that these risk variables have more than one subcomponent, it is essential to examine the effects of these variables on economic growth more comprehensively. In this study, the effect of economic, financial, and political risk ratios on 
economic growth is examined for Turkey during the period of 2000:01-2020:06. For this purpose, the following tests were used: the Toda-Yamamoto causality test, the Bootstrap Toda-Yamamoto causality test developed by Hatemi-J, and the time-varying symmetric and asymmetrical causality tests of the Hatemi-J test, which examine the causality relationship in terms of sub-periods.

According to the findings, The Toda-Yamamoto causality test shows a causal relationship between the financial risk variable and economic growth, between the economic risk variable and the financial risk variable, and between the economic risk variable and the political risk variable. According to the Bootstrap Toda-Yamamoto causality test findings, there is a causality relationship between the financial risk variable and economic growth. According to the Bootstrap Toda-Yamamoto asymmetric causality test findings, it is seen that economic growth reacts positively to the positive shock arising from the financial risk variable, while economic growth responds negatively to an adverse shock. A negative shock in the political risk variable causes a positive shock on economic growth. According to the time-varying symmetric causality test findings, in general terms, the periods in which there is a causal relationship between the economic risk variable and economic growth are the following: in the periods 2003:12-2012:02, 2014:06-2017:05, 2018:01-2020:06; economic growth is affected by the financial risk variable in the period of 2000:02-2011:05 and by the political risk variable in the period of 2002:01-2018:05. According to the time-varying asymmetric causality test findings, it is seen that negative shocks in the economic risk variable affect economic growth positively in the period of 2010:05-2020:06, and the positive shocks in the economic risk variable affect economic growth negatively in the period of 2013:11-2019:04. These shocks positively affect the financial risk variable in the period 2010:05-2020:06, while having a negative effect in the period of 2011:02-2018:07. The effects of shocks in economic and financial risk variables on economic growth occurred in similar periods. This situation strengthens the theoretical view that economic and financial risks support each other. Even though the political risk variable caused no positive shock to economic growth in the said period, there was an increase in the political risk ratio in the 2011:05-2017:01 period, which negatively affected the economic growth. When the effect of risk types on economic growth is evaluated generally, improvement or deterioration in all these risk types in Turkey has positive or negative effects on economic growth. In addition, in recent years, the effect of economic and financial risks has been stronger than the effect of political risk on economic growth. In the light of this information, it can be said that it is necessary to take policies and measures to reduce economic and financial risks. In this context, there has been a deterioration in economic growth in Turkey recently, especially after 2012; Indicators such as GDP per capita, exchange rate, budget balance, inflation rate, current account balance, and external debts show that remedial measures should be taken. 


\section{Giriş}

Ekonomik büyüme, ekonomi bilimi içinde araştırmacıların ilgiyle üzerinde durduğu alanlardan biri olmaya devam etmektedir. Çünkü ülkelerin büyüme oranlarında meydana gelen küçük artışlar, o ülkelerin refah ve yaşam standartlarını değiştirebilecek büyük etkiler yaratabilmektedir. Ülkelerin farklı büyüme performanslarına sahip olması ülkeler arasında kişi başına gelir ve yaşam standartları gibi göstergelerde büyük farklılıkların ortaya çıkmasına neden olmuştur (Acemoğlu, 2012). Böylelikle ülkeler arasındaki gelişmişlik farklarının nedenlerini araştırmak iktisatçıların gündeminde yer almıştır (Jones, 2017).

Gelişmişlik farklarını literatürde temel olarak inceleyen yaklaşımlar bulunmaktadır. Bunlardan birincisi üretim fonksiyonu yaklaşımıdır. Bu yaklaşıma göre bu farklılıkların nedeni teknoloji düzeyi, fiziksel ve beşeri sermaye düzeyi, doğal kaynakların daha iyi kullanılması gibi unsurlardan kaynaklanmaktadır. İkincisi, coğrafya-lokasyon yaklaşımıdır. $\mathrm{Bu}$ yaklaşıma göre gelişmişlik farklılıkları, ülkelerin sahip olduğu iklim koşulları ve lokasyon gibi faktörlere bağlıdır. Üçüncüsü ise kurumsal yaklaşımdır. Bu yaklaşıma göre gelişmişlik farklıkları mülkiyet haklarının korunması, piyasa ekonomisinin işlemesi ve mübadele özgürlüğü gibi faktörlere bağlıdır. Buna ilave olarak istikrar göstergeleri de (ekonomik, finansal ve politik) ülkeler arasındaki gelişmişlik farklılıkları açısından önem arz etmektedir (Beşkaya \& Koç, 2006). Çünkü istikrarlı bir yapı, ülke ekonomilerinde daha büyük ekonomik büyümeye ulaşabilmek için uygun ortamı oluşturmaktadır. Ayrıca istikrar ile birlikte ekonomik büyüme ve sürdürülebilirlik de kendiliğinden sağlanmaktadır (Fischer, 1993).

Ekonomik istikrarın sağlanması ülkelerin ekonomik yapısı için büyük önem arz etmektedir (Fischer, 1993). Çünkü ekonomik istikrarın sağlanması ülkelerin makroekonomik göstergeleri (düşük enflasyon, uygun reel faiz oranı, reel döviz kurunun öngörülebilirliği, mali disiplin gibi) aracılığıyla ekonomik büyümeye yansımaktadır. Buna ilave olarak ekonomik istikrar ile finansal istikrar da birbiri ile yakın bir ilişki içerisindedir. Çünkü ekonomik istikrardaki bir bozulma anında finansal sistemi etkileyebilmekte, aynı şekilde finansal sistemdeki bir bozulma da ekonomik istikrarı etkileyebilmektedir. Finansal sistemlerdeki bu istikrarsızlık ekonomik büyümeyi üç ayrı kanaldan etkilemektedir. Birincisi, finansal sistemdeki istikrarsızlık ekonomide belirsizliği artırarak varlık fiyatlarındaki oynaklığa neden olmaktadır. Bu oynaklık firmaların yatırım kararlarını ve tüketicilerin harcama eğilimlilerini azaltmaktadır. Bunların sonucu olarak üretim düşmekte ve ekonomik büyüme olumsuz etkilenmektedir. İkincisi, finansal sistemdeki istikrarsızlık borçlanma koşullarının bozulmasıyla, borç alacaklar için fon elde etme zorlaştığından ekonomik büyüme olumsuz etkilenmektedir. Üçüncüsü, finansal sistemdeki istikrarsızlık, firmaların yatırım ve hanehalklarının tüketim harcamalarının finansmanında kullanılacak 
fon maliyetlerini artırarak da ekonomik büyümeyi olumsuz etkilemektedir (Karamelikli \& Bayar, 2016). Ekonomik ve finansal istikrarsızlığın yanı sıra son zamanlarda, ekonomik büyüme literatüründe, politik istikrarsızlığın veya politik riskin büyüme üzerindeki etkisini araştıran çalışmalar artmıştır. Ekonomik büyümeyi etkileyen unsurlardan politik istikrarsızlık, belirsizlik yarattığ 1 için ekonomik büyümede gerilemeye yol açmaktadır. Çünkü yatırım ve tasarruflardaki gerileme üretimi azaltarak ekonomik büyümeyi yavaşlatacaktır. Ayrıca büyüme oranlarının düşük olması da politik istikrarsızlıktaki artışı körüklemektedir (Asteriou \& Price, 2001). Dolayısıyla birbirini etkileyen bir ilişki söz konusudur. Bu bilgiler 1şı̆̆ında son dönemde yaşanan olaylar (savaş, terör olayları, pandemi gibi) sonucunda artan ülke risklerinin (ekonomik, finansal ve politik) ekonomik büyümeyi etkileyip etkilememe durumunun incelenmesinde fayda vardır. Çünkü ülkelerin hangi risklerle karşı karşıya olduklarını bilmeleri ve bu risklerin oluşturacağı etkiyi iyi analiz etmeleri büyük önem arz etmektedir.

Konuyla ilgili literatürdeki çalışmalar incelendiğinde, Das ve Loxley (2015), Berber ve Artan (2004) ve Barro (1995) enflasyonla büyüme arasındaki ilişkiyi; Kutlu ve Yurttagüler (2016) ve Pattillo ve ark. (2011) dış borçla ekonomik büyüme arasındaki ilişkiyi; Kenourgios ve Samitas (2007) ve Dudian ve Popa (2013) krediler ile ekonomik büyüme arasındaki ilişkiyi; Soytaş ve Küçükkaya (2011), Christopoulos ve Tsionas (2004), Calderon ve Liu (2003) ve Caporale ve ark. (2009), finansal gelişme ile ekonomik büyüme arasındaki ilişkiyi incelemektedir. Feng (2001), Chen ve Feng (1996), Tang ve Abosedra (2014), Çela ve Hysa (2021) ve Pasha (2020) gibi pek çok çalışma ise politik göstergeler ile büyüme arasındaki ilişkiyi araştırmışlardır. Bu çalışmaların ortak özelliği; ekonomik, finansal ve politik değişkenlerin ekonomik büyüme üzerindeki etkisini bir alt bileşene dayalı olarak dar kapsamda ele almasıdır. Oysa söz konusu risk değişkenlerinin birden fazla alt bileşene sahip olduğu dikkate alındığında bu değişkenlerin ekonomik büyüme üzerine etkisinin daha kapsamlı olarak incelenmesi önem arz etmektedir. Çünkü son dönemlerde yüksek enflasyon, zayıf büyüme ve yüksek dış açık gibi makroekonomik göstergelerdeki bozulmalar Türkiye ekonomisinin kırılganlığını artırmıştır. Buna ilave olarak siyasi gerginliklerin artması, ülkenin jeopolitik konumu nedeniyle terör olayları ve etnik gerilimlerin yaşanması gibi pek çok politik sorun da bu ekonomik kırılganlığı tetiklemiştir. Bu bilgiler 1şığında çalışma ekonomik, finansal ve politik risklerin alt bileşenlerinin ekonomik büyüme üzerine etkisinin olacağını iddia etmektedir. Bu bağlamda çalışmanın temel amacı Türkiye'deki ekonomik, finansal ve politik riskler ile büyüme arasındaki ilişkiyi 2000:01-2020:06 dönemine ait verilerle araştırmaktır. Bu çalışmanın literatürde incelenen diğer çalışmalardan farkı; enflasyon, dış borçlanma, finansal gelişme, seçimler, terörizm gibi değişkenleri ayrı ayrı kullanmak yerine ekonomik ( 5 alt bileşen), finansal ( 5 alt bileşen) ve politik (12 alt bileşen) olarak her birini tek bir risk grubu altında toplulaştırmasıdır. Böylece söz konusu risk 
göstergeleriyle ekonomik büyüme arasındaki ilişkinin daha kapsamlı olarak incelenmesinin literatüre katkı sağlayacağı düşünülmektedir.

Çalışma dört bölümden oluşmaktadır. İkinci bölümde konuya ilişkin literatür incelenmekte üçüncü bölümde veri, yöntemler ve ampirik bulgular bulunmaktadır. Son bölümde ise araştırmanın sonuçları ve politika önerisi sunulmaktadır.

\section{Literatür}

Türkiye ekonomisi yüksek enflasyon, zayıf büyüme ve yüksek dış açık gibi göstergelere sahip olması nedeniyle kırılgan bir ekonomik yapıya sahiptir. Ayrıca Türkiye'de son dönemlerde siyasi gerginliklerin artması, ülkenin jeopolitik konumu nedeniyle terör olayları ve etnik gerilimlerin yaşanması gibi pek çok politik sorun bulunmaktadır. Bu bağlamda büyümeyi etkileyen ekonomik, finansal risk göstergelerinin yanında politik risk göstergelerini dikkate alarak araştırma yapmak önem arz etmektedir. Bu nedenle konu ile ilgili literatürdeki çalışmalar incelenmiştir. Ekonomik risk ile büyüme arasındaki ilişkiyi inceleyen çalışmalar; enflasyon ve büyüme Berber ve Artan (2004), Das ve Loxley (2015)), işsizlik ve büyüme Kanca (2012), Muscatelli ve Tirelli (2001), diş borçlar ve büyüme (Kamac1 (2016), Uçak (2017), Kutlu ve Yurttagüler (2016), Pattillo ve ark. (2011) şeklindedir. Bu çalışmalardan enflasyon ve büyüme arasında Berber ve Artan (2004) negatif, Das ve Loxley (2015) pozitif ilişki; işsizlik ve büyüme arasında Muscatelli ve Tirelli (2001) negatif ilişki, Kanca (2012) ise büyüme oranından işsizliğe tek yönlü nedensellik ilişkisi olduğunu tespit etmiştir. Ayrıca Kamacı (2016), Uçak (2017), Kutlu ve Yurttagüler (2016) dış borçlardan büyümeye doğru tek yönlü nedensellik, Pattillo ve ark. (2011) doğrusal olmayan negatif bir ilişki bulmuştur. Finansal risk ile büyüme arasındaki ilişkiyi inceleyen çalışmalar; kredi ve büyüme Kenourgios ve Samitas (2007), Dudian ve Popa (2013), finansal gelişme ve büyüme Calderon ve Liu (2003), Soytaş ve Küçükkaya (2011), Christopoulos ve Tsionas (2004), Akimov ve ark., (2009) şeklindedir. Bu çalışmalardan Kenourgios ve Samitas (2007) ve Dudian ve Popa (2013) kredilerin ekonomik büyümeyi etkilediğini bulmuşlardır. Calderon ve Liu (2003) finansal gelişme ile ekonomik büyüme arasında çift yönlü, Caporale ve ark., (2009) ve Christopoulos ve Tsionas (2004) tek yönlü nedensellik ilişkisi bulurken, Soytaş ve Küçükkaya (2011) ilişki bulamamıştır.

Politik risk/istikrarsızlık/istikrar ile büyüme arasındaki ilişkiyi inceleyen çalışmalar; Asteriou ve Price (2001); Feng (2001); Şanlısoy ve Kök (2010); Gür, Akbulut (2012); Arslan (2011); Jong-A-Pin (2009); Demez ve ark. (2019); Gurgul ve Lach (2013); Yalçınkaya ve Kaya (2017); Kamacı (2019); Campos ve Nugent (2002); Brückner ve Gradstein (2015); Tang ve Abosedra (2014); Alper (2018); Radu (2015); Younis vd., (2008); Zouhaier ve Kefi (2012); Demirgil (2011); Aisen ve Veiga (2013); Parlakyıldız (2015); Baklouti ve Boujelbene 
(2018); Kartal ve Öztürk (2020); Nazeer ve Masih (2017); Çela ve Hysa (2021); Okafor (2015); Pasha (2020); Kızılkaya ve Sofuoğlu (2016) şeklindedir. Bu çalışmalar elde edilen bulgulara göre değerlendirilecek olursa; Gür, Akbulut (2012); Alper (2018); Radu (2015); Younis ve ark., (2008); Baklouti ve Boujelbene (2018); Kartal ve Öztürk (2020); Çela ve Hysa (2021) politik istikrar ile ekonomik büyüme arasında olumlu ilişki bulurken; Asteriou ve Price (2001); Feng (2001); Campos ve Nugent (2002); Jong-A-Pin (2009); Şanlısoy ve Kök (2010); Demirgil (2011); Aisen ve Veiga (2013); Gurgul ve Lach (2013); Tang ve Abosedra (2014); Okafor (2015); Parlakyıldız (2015); Nazeer ve Masih (2017); Pasha (2020) politik istikrarsızlık ile ekonomik büyüme arasında olumsuz ilişki bulmuşlardır. Politik istikrarsızlık ve ekonomik büyüme arasında Yalçınkaya ve Kaya (2017) G12 ülkelerinde olumlu, G8 ülkelerinde olumsuz etki; Kamacı (2019) kısa dönemde olumlu, uzun dönemde olumsuz sonuçlar elde etmişlerdir. Politik istikrarsızlık ve ekonomik büyüme arasında Zouhaier ve Kefi (2012) ilişki olmadığını; Demez vd. (2019); Kızılkaya ve Sofuoğlu (2016); Arslan (2011); Brückner ve Gradstein (2015) ise büyümeden politik istikrara doğru tek yönlü ilişki bulmuşlardır. İncelenen literatürde ekonomik, finansal ve politik risk göstergelerinin ekonomik büyüme üzerindeki etkisi örneklem, zaman gibi unsurlara göre değişiklik göstermektedir.

\section{Veri ve Yöntem}

Bu çalışmada, ekonomik, finansal ve politik risk ile büyüme arasındaki ilişki 2000:012020:06 dönemi için Toda-Yamamoto nedensellik testi, Bootstrap Toda-Yamamoto nedensellik testi ve zamanla değişen simetrik ve asimetrik nedensellik testleri ile analiz edilmiştir. Değişkenlerin logaritması alınmıştır. Analizlerde kullanılacak değişkenlerle ilgili bilgiler Tablo 1'de gösterilmiştir.

Tablo 1: Analizlerde Kullanılacak Değişkenlerin Açıklanması

\begin{tabular}{lcc}
\hline Değişkenler & Açıklama & Kaynak \\
\hline IPI $^{1}$ & Sanayi Üretim Endeksi & TCMB/EVDS \\
ER & Ekonomik Risk Oranı & PRS Group ICRG Veriseti \\
FR & Finansal Risk Oranı & PRS Group ICRG Veriseti \\
PR & Politik Risk Oranı & PRS Group ICRG Veriseti \\
\hline
\end{tabular}

Çalışma kapsamında incelenen riskler; ekonomik, finansal ve politik risklerdir. Bu riskler Uluslararası Ülke Riski Rehberi’nde ${ }^{2}$ yayınlanmaktadır. Ülkelerin ekonomik, finansal ve

\footnotetext{
${ }^{1}$ Çalışmada aylık verilerle çalışılmak istenilmektedir. Ancak iktisadi büyüme oranları ve/veya Gayrisafi Yurtiçi Hasıla aylık olarak açıklanmamaktadır. Bunun için literatür dikkate alınarak büyümeyi temsilen en yakın gösterge olan sanayi üretim endeksi kullanılmıştır.

${ }^{2}$ International Country Risk Guide-ICRG (bkz: https:/www.prsgroup.com/explore-our-products/internationalcountry-risk-guide/)
} 
politik açıdan risk endekslerini oluşturan PRS-ICRG kuruluşunun hazırladığı veriler birçok ampirik çalışmada tercih edilmektedir (bkz: Howell \& Chaddick (1994), Belkhir ve ark. (2018), Gregory (2019), Yapraklı \& Güngör (2007), Üçler (2017)).

ICRG'nin yayınladığı veriler, üç risk kategorisinde (ekonomik, finansal ve politik) 22 değişken içermektedir. Bu değişkenlerin her biri için ayrı bir dizin oluşturulmaktadır. Ekonomik, finansal ve politik risk oranları sırasıyla 50 puan, 50 puan ve 100 puan üzerinden değerlendirilmektedir. Her bir endeks için risk puanları ne kadar düşükse/yükssekse, risk o kadar yüksek/düşük olmaktadır. Ekonomik risk; kişi başına GSYH, reel GSYH büyüme oranı, yıllık enflasyon oranı, bütçe dengesi/ GSYH, cari hesap/ GSYH; Finansal risk; diş borçlar/GSYH, dış borç servisi/mal ve hizmet ihracatı, ithalatın yapıldığı aylar bazında net uluslararası likidite, döviz kuru istikrarı olmak üzere 5'er alt bileşenden oluşmaktadır. Politik risk; hem politik hem de sosyal nitelikleri kapsayan 12 alt bileşenden (hükümet istikrarı, sosyo-ekonomik koşullar, yatırım profili, iç çatışmalar, dış çatışmalar, yolsuzluk, politikada ordunun etkisi, dinsel gerilimler, hukuk ve düzen, etnik gerilimler, demokratik hesap verilebilirlik, bürokrasinin niteliği) oluşmaktadır (ICRG, 2020).

Ekonomik, finansal ve politik risk ile büyüme arasındaki ilişkiyi incelemek için dört aşamalı bir süreç izlenmiştir. Birinci aşamada, değişkenlerin durağanlıkları incelenmektedir. İkinci aşamada değişkenler arasında Toda-Yamamoto nedensellik analizi ve Bootstrap TodaYamamoto nedensellik testi yapılmaktadır. Üçüncü aşamada değişkenler arasında nedenselliğin alt dönemler itibariyle incelenmesi amaciyla Hacker ve Hatemi-J (2006) dayalı olarak geliştirilen zamanla değişen simetrik nedensellik testi uygulanmaktadır. Son aşamada ise ortaya çıkan olumlu ve olumsuz gelişmelerin büyüme üzerine yaratmış olduğu negatif ve pozitif şokların ortaya konulabilmesi için Hatemi-J (2012) dayalı olarak geliştirilen zamanla değişen asimetrik nedensellik testi yapılmaktadır.

Tablo 2: Değişkenlere Ait Bazı Tanımlayıcı İstatistikler

\begin{tabular}{lcccc}
\hline & LNIPI & LNFR & LNER & LNPR \\
\hline Mean & 1.856549 & 1.514426 & 1.504171 & 1.761701 \\
Median & 1.851502 & 1.518514 & 1.531479 & 1.755875 \\
Maximum & 2.113910 & 1.585461 & 1.556303 & 1.848189 \\
Minimum & 1.560583 & 1.371068 & 1.243038 & 1.698970 \\
Std. Dev. & 0.148890 & 0.046870 & 0.062487 & 0.038166 \\
Skewness & -0.177242 & -1.059622 & -2.143471 & 0.557360 \\
Kurtosis & 1.932965 & 4.183286 & 8.498041 & 2.363416 \\
Jarque-Bera & 12.95829 & 60.38646 & 498.2149 & 16.89034 \\
Probability & 0.001535 & 0.000000 & 0.000000 & 0.000215 \\
Sum & 456.7111 & 372.5489 & 370.0261 & 433.3784 \\
Sum Sq. Dev. & 5.431199 & 0.538214 & 0.956628 & 0.356875 \\
Observations & 246 & 246 & 246 & 246 \\
\hline
\end{tabular}


Ekonometrik çalışmalarda serilerin durağan olması oldukça önemlidir. Çünkü durağan olmayan zaman serileri ile analiz yapılması durumunda sahte regresyon sorunuyla karşılaşılmaktadır (Gujarati, 1995). Bu durumda elde edilen tahminler sapmalıdır. Bundan dolayı değişkenlerin durağanlıklarının incelenmesi gerekmektedir. $\mathrm{Bu}$ çalışmada ekonometrik analizlerde yaygın olarak tercih edilen Genişletilmiş Dickey-Fuller (1981) (ADF) ile Philips ve Peron (1988) (PP) testleri kullanılmıştır.

Tablo 3: ADF ve PP Test Sonuçları

\begin{tabular}{|c|c|c|c|c|c|c|c|c|c|c|}
\hline & \multirow{3}{*}{ Değiş̧. } & \multicolumn{4}{|c|}{ ADF } & \multicolumn{4}{|c|}{$\mathbf{P P}$} & \multirow[b]{3}{*}{ Sonuç } \\
\hline & & \multicolumn{2}{|c|}{ Düzey } & \multicolumn{2}{|c|}{ Farkı } & \multicolumn{2}{|c|}{ Düzey } & \multicolumn{2}{|c|}{ Farkı } & \\
\hline & & Test ist. & Prob & Test ist. & Prob & Test ist. & Prob & Test ist. & Prob & \\
\hline \multirow{4}{*}{ Sabitli } & IPI & -1.010 & 0.749 & -5.482 & 0.000 & -2.280 & 0.179 & -59.342 & 0.001 & $\mathrm{I}(1)$ \\
\hline & ER & -3.101 & 0.027 & & & -3.033 & 0.033 & & & $\mathrm{I}(0)$ \\
\hline & PR & -1.664 & 0.447 & -16.887 & 0.000 & -1.537 & 0.513 & -17.061 & 0.000 & $\mathrm{I}(1)$ \\
\hline & FR & -3.622 & 0.006 & & & -3.552 & 0.007 & & & $\mathrm{I}(0)$ \\
\hline \multirow{4}{*}{$\begin{array}{l}\text { Sabit } \\
\text { ve } \\
\text { trendli }\end{array}$} & IPI & -2.307 & 0.428 & -5.455 & 0.000 & -8.749 & 0.000 & & & $\mathrm{I}(0)$ \\
\hline & ER & -3.429 & 0.049 & & & -3.512 & 0.040 & & & $\mathrm{I}(0)$ \\
\hline & PR & -3.039 & 0.123 & -16.884 & 0.000 & -2.976 & 0.140 & -17.112 & 0.000 & $\mathrm{I}(1)$ \\
\hline & FR & -4.577 & 0.001 & & & -4.716 & 0.001 & & & $\mathrm{I}(0)$ \\
\hline
\end{tabular}

Değişkenlerin durağanlıkları ADF ve PP testleriyle analiz edilmiştir. IPI sabitli modelde farkında durağan, sabitli ve trendli modelde ise düzeyde durağandır. PR hem sabitli hem de sabit ve trendli modelde farkında durağan yani I(1) iken, modelde yer alan diğer değişkenler; ER ve FR düzeyde durağan yani I(0)'dır.

\subsection{Toda- Yamamoto Nedensellik Testi}

Toda-Yamamoto nedensellik testi Granger nedensellik testinin geliştirilmiş halidir. Bu test Granger nedensellik testindeki bazı muhtemel eksiklikleri gidermektedir. TodaYamamoto nedensellik testinde seriler arasında ilişkilerin, durağanlık ve eşbütünleşme bilgisine ihtiyaç duyulmamaktadır. Bu durum söz konusu testin geçerliliğini engellememektedir. Bu yöntemin daha güçlü sonuçlar elde edildiği düşünülmesinin nedeni fark almadan kaynaklı, gözlem sayısı ve bilgi kaybı olmamasıdır. Bundan dolayı ekonomik, finansal ve politik risk ile büyüme arasındaki ilişkiyi incelemek için Toda-Yamamoto nedensellik testi kullanılmıştır. Testinin uygulanabilirliği için öncelikle VAR modeli oluşturulmakta ve uygun gecikme uzunluğu belirlenmektedir. Gecikme uzunluğuna ilişkin sonuçlar Tablo 4'te yer almaktadır. 
Tablo 4: Gecikme Uzunlukları

\begin{tabular}{lcccccc}
\hline Lag & LogL & LR & FPE & AIC & SC & HQ \\
\hline 0 & 1522.616 & NA & $3.37 \mathrm{e}-11$ & -12.76148 & -12.70313 & -12.73796 \\
1 & 2408.811 & 1735.154 & $2.25 \mathrm{e}-14$ & -20.07404 & $\mathbf{- 1 9 . 7 8 2 2 6 *}$ & -19.95645 \\
2 & 2442.236 & 64.32148 & $1.94 \mathrm{e}-14$ & -20.22047 & -19.69525 & $\mathbf{- 2 0 . 0 0 8 8 0 *}$ \\
3 & 2464.641 & 42.36325 & $1.84 \mathrm{e}-14$ & -20.27430 & -19.51565 & -19.96855 \\
4 & 2484.666 & 37.18797 & $1.78 \mathrm{e}-14$ & -20.30811 & -19.31604 & -19.90829 \\
5 & 2497.249 & 22.94670 & $1.84 \mathrm{e}-14$ & -20.27941 & -19.05390 & -19.78550 \\
6 & 2519.426 & 39.69425 & $1.74 \mathrm{e}-14$ & -20.33131 & -18.87237 & -19.74333 \\
7 & 2541.106 & 38.07649 & $1.67 \mathrm{e}-14$ & -20.37904 & -18.68667 & -19.69699 \\
8 & 2572.344 & $\mathbf{5 3 . 8 1 3 8 3 *}$ & $\mathbf{1 . 4 7 e - 1 4 *}$ & $\mathbf{- 2 0 . 5 0 7 0 9 *}$ & -18.58130 & -19.73096 \\
\hline
\end{tabular}

Tablo 4'te yer alan sonuçlara göre LR, FPE, AIC kriterlerine göre modelin gecikme sayıs1 8, SC kriterine göre 1, HQ kriterine göre 2'dir. Elde edilen bulgulara göre, uygulamada sıklıkla kullanılmasının yanında daha fazla bilgi kriteri içerdeği için LR ve AIC sonuçları dikkate alınarak uygun gecikme uzunluğu 8 olarak seçilmiştir.

Tablo 5: Toda-Yamamoto Nedensellik Testi Sonuçları

\begin{tabular}{lccc}
\hline Hipotezler & Gecikme Sayısı(p+d) & Ki-Kare Değeri & Olasıllk Değeri \\
\hline FR, IPI'nın Granger nedeni değildir. & 9 & $7.900853^{*}$ & $0.0049^{*}$ \\
ER, IPI'nın Granger nedeni değildir. & 9 & 0.007103 & 0.9328 \\
PR, IPI' nın Granger nedeni değildir. & 9 & 0.326549 & 0.5677 \\
IPI, FR' nin Granger nedeni değildir. & 9 & 1.876265 & 0.1708 \\
ER, FR' nin Granger nedeni değildir. & 9 & $7.851351^{*}$ & $0.0051^{*}$ \\
PR, FR'nın Granger nedeni değildir. & 9 & 2.236200 & 0.1348 \\
IPI, ER'nin Granger nedeni değildir. & 9 & 0.001881 & 0.9654 \\
FR, ER'nin Granger nedeni değildir. & 9 & 0.073924 & 0.7857 \\
PR, ER'nin Granger nedeni değildir. & 9 & 0.811589 & 0.3677 \\
IPI, PR'nin Granger nedeni değildir. & 9 & 1.326161 & 0.2495 \\
FR, PR'nin Granger nedeni değildir. & 9 & 1.451710 & 0.2283 \\
ER, PR'nin Granger nedeni değildir. & 9 & $4.780598^{* *}$ & $0.0288^{* *}$ \\
\hline
\end{tabular}

*, ** sırasıyla \%1 ve \%5'e göre istatistiki olarak anlamlılığı göstermektedir.

Tablo 5'te yer alan sonuçlara göre, FR, IPI değişkenine ve ER, FR değişkenine \%1 anlamlılık düzeyinde Granger neden iken, ER, PR değişkenine \%5 anlamlılık düzeyinde Granger neden olmaktadir.

\subsection{Zamanla Değișen Simetrik ve Asimetrik Nedensellik Testi}

Hacker ve Hatemi-J (2006), Toda-Yamamoto (1995) testinin üstün özelliklerini kullanarak bootstrap'a dayalı bir nedensellik testi geliştirmişlerdir. Söz konusu özelliklerin en önemlileri değişkenlerin durağanlık düzeyleri farklı olabilmekte ve eşbütünleşme ilişkisi zorunluluğu bulunmamaktadır. Hacker ve Hatemi-J (2006) testte meydana gelebilecek değişen varyans sorununu çözebilmek için testi bootstrap yöntemine dayalı olarak 
geliştirmiştir (Kırca \& Yıldız, 2020, s. 21). Toda ve Yamamoto (1995) tarafından değişkenler arasında Granger nedenselliği analiz etmek için modifiye edilmiş Wald testi (MWALD) aşağıdaki şekilde tanımlanır:

$$
M W A L D=(C \hat{\beta})^{\prime}\left[C\left(\left(Z Z^{\prime}\right)^{-1} \Theta S_{U}\right) C^{\prime}\right]^{-1}(C \hat{\beta})
$$

Denklemde, $\Theta$ kronecker çarpanı ve $C,(1+n(p+d)) \times 1)$ matrisidir. $S_{U}=\hat{\delta}^{\prime} \hat{\delta}_{U} / T$ olarak $\beta=\operatorname{vec}\left(\mu_{0}, \mu_{1}, \ldots, \mu_{p}, 0_{n \times n d}\right)$ ve $\hat{\beta}=\operatorname{vec}(\hat{D})$ ile gösterilmektedir. Hacker ve Hatemi- J (2006), $\chi^{2}$ dağılımına sahip olan MWALD testinin bootstrap tekniğin kullanılarak yapılması durumunda bazı problemleri (sonlu örneklemde doğru boyutunun sağlanmaması sonucunda ortaya çıkan yanıltıcı sonuçlar gibi) ortadan kaldırabileceğini ve böylelikle tahmindeki sapmaların azaltılabileceğini ileri sürmüştür.

Zamanla değişen nedensellik yöntemin temeli, Hacker ve Hatemi-J (2006) tarafindan geliştirilen yönteme dayanmaktadır. Ancak Hacker ve Hatemi-J (2006) nedensellik testinde örneklemin tamamı dikkate alınırken, zamanla değişen nedensellik testinde ise örneklemin alt dönemleri dikkate alınmaktadır. Bu alt dönemler aşağıdaki gibi tanımlanmaktadır:

$$
t=\tau-l+1, \tau-l, \ldots, \tau, \tau=l, l+1, \ldots, T
$$

Denklemde $l$ : yuvarlanan pencere büyüklüğünü ifade etmektedir. Böylelikle zamanla değişen nedensellik testinde her bir alt döneme nedensellik testi uygulanmaktadır. Bu yöntemde önemli unsur, Brooks ve Hinich'in (1998) belirttiği gibi alt dönemin uzunluğunu belirlemektir. Bu doğrultuda Caspi (2017) çalışması dikkate alınarak alt dönem sayısı belirlenmektedir. Çalışmanın alt dönem sayısı $T(0.01+1.8 / \sqrt{T})$ formülü kullanılarak 30 olarak belirlenmiştir. Elde edilen test istatistiklerinin anlamlılığı her gözlem aralığında elde edilen test istatistiği bootstrap ${ }^{3}$ kritik değeri ile normalleştirilmektedir. Her gözlem aralığında elde edilen test istatistiği, bu gözlem aralığında elde edilen \%10 bootstrap kritik değeri ile kıyaslanmaktadır. Her bir alt dönem için periyodik test istatistik değeri hesaplanmaktadır. ${ }^{4}$ Elde edilen Wald test istatistik değerleri yorumlanmak üzere grafiğe dökülür. Bu grafikte bu test istatistik değerlerinin "1" den büyük olduğu dönemler için bir nedensellik ilişkisi bulunur (Erdoğan, Gedikli \& Kırca, 2019; Yılancı \& Bozoklu, 2014).

Granger ve Yoon (2002), serilerin belirli bir türdeki şoka birlikte karşılık verebileceklerini belirterek, veriyi birikimli pozitif ve negatif parçalarına ayrıştırmıştır. Hatemi-J (2012) ise Granger ve Yoon (2002) yaklaşımını nedensellik analizi için geliştirmiştir. Hatemi- J (2012:449), $y_{1 t}$ ve $y_{2 t}$ gibi aralarında nedensellik ilişkisi araştırılan ve bütünleşik olan iki seriyi aşağıdaki gibi tanımlanmıştır:

\footnotetext{
${ }^{3}$ Bootstrap yöntemi bu çalışma için 10000 olarak belirlenmiştir.

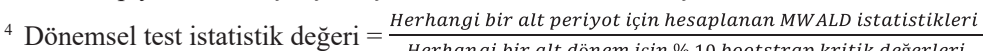




$$
\begin{aligned}
& y_{1 t}=y_{1 t-1}+\varepsilon_{1 t}=y_{1,0}+\sum_{Y=1}^{t} \varepsilon_{1 i} \\
& y_{2 t}=y_{2 t-1}+\varepsilon_{2 t}=y_{2,0}+\sum_{Y=1}^{t} \varepsilon_{2 i}
\end{aligned}
$$

Değişkenlerin tanımımda yer alan $y_{1,0}$ ve $y_{2,0}$ başlangıç değerlerini, $\varepsilon_{1 i} \varepsilon_{1 i}$ ve $\varepsilon_{2 i} \varepsilon_{2 i}$ ise değişkenlerin içinde var olan şokların toplamını ifade etmektedir. Denklem (5)'de her değişkende yer alan pozitif ve negatif şoklar birikimli formda ifade edilmektedir:

$$
y_{1 i}^{+}=\sum_{Y=1}^{t} \varepsilon_{1 i}^{+}, \quad y_{1 i}^{-}=\sum_{Y=1}^{t} \varepsilon_{1 i}^{-}, \quad y_{2 i}^{+}=\sum_{Y=1}^{t} \varepsilon_{2 i}^{+}, y_{2 i}^{-}=\sum_{Y=1}^{t} \varepsilon_{2 i}^{-},
$$

$y_{1 t}^{+}$birinci değişkene ait pozitif şokları, $y_{1 t}^{-}$birinci değişkene ait negatif şokları, $y_{2 t}^{+}$ikinci değişkene ait pozitif şokları ve son olarak $y_{2 t}^{-}$ikinci değişkene ait negatif şokları ifade etmektedir.

Bu çalışmada Hatemi-J (2012) tarafından geliştirilen asimetrik nedensellik testinin zamanla değişen formu kullanılmaktadır. Böylelikle pozitif ve negatif şoklar arasındaki nedensellik ilişkisinin istikrarlı olup olmadığı sınanmaktadır. Zamanla değişen asimetrik nedensellik analizi için alt örnek boyutu simetrik analizde olduğu gibi 30'dur. Daha sonraki işlemler simetrik analizde olduğu gibi tekrarlanmaktadır. Ayrıca bu çalışmada, uygun gecikme uzunluğuna Hatemi-J (2003)'nin literatüre kazandırdığı bilgi kriteri kullanılarak karar verilmiş ve bu uygun gecikme uzunluğuna göre belirlenmiş olan VAR modele 1 gecikme eklenmiştir.

Tablo 6: Hatemi-J Nedensellik Testi Bulguları

\begin{tabular}{lcccccccc}
\hline & & Test İst. & \multicolumn{4}{c}{ Kritik değerler } & \multicolumn{2}{c}{ Nedensellik } \\
\cline { 3 - 7 } & & & $\mathbf{P}$ & $\mathbf{\% 1}$ & $\mathbf{\% 5}$ & $\mathbf{\% 1 0}$ & \\
\hline ER & IPI & 0.083 & 1 & 7.088 & 3.946 & 2.766 & & Yok \\
FR & IPI & $7.237^{* * *}$ & 1 & 6.830 & 3.766 & 2.681 & Var \\
PR & IPI & 0.819 & 1 & 7.042 & 4.035 & 2.813 & Yok \\
\hline
\end{tabular}

Not: ***\%1 düzeyindeki anlamlllı̆gi ifade etmektedir. P, uygun gecikme uzunluğunu temsil etmektedir. Ayrnca p, Hatemi-J (2003) kriteriyle tespit edilen VAR modele ek olarak bir gecikme eklenmesi ile elde edilmiştir. Uygun kritik değerler 10000 bootstrap simülasyonu ile elde edilmiştir.

Tablo 6' da elde edilen Hatemi-J nedensellik testi bulgularına göre; finansal risk değişkeninden büyümeye doğru bir nedensellik ilişkisi söz konusudur. Buna karşın ekonomik risk ve politik risk değişkenlerinden büyümeye doğru bir nedensellik ilişkisi bulunamamıştır. 
Tablo 7: Hatemi-J Asimetrik Nedensellik Testi Bulguları

\begin{tabular}{|c|c|c|c|c|c|c|c|}
\hline & & \multirow[t]{2}{*}{ Test İst. } & \multicolumn{4}{|c|}{ Kritik değerler } & \multirow[t]{2}{*}{ Nedensellik } \\
\hline & & & $\mathbf{P}$ & $\% 1$ & $\% 5$ & $\% 10$ & \\
\hline \multirow{4}{*}{$\mathrm{ER} \rightarrow$ IPI } & $+\rightarrow+$ & 0.836 & 1 & 9.583 & 4.228 & 2.532 & Yok \\
\hline & $-\rightarrow-$ & 0.044 & 1 & 12.336 & 3.967 & 2.300 & Yok \\
\hline & $-\rightarrow+$ & 0.081 & 1 & 9.489 & 4.098 & 2.496 & Yok \\
\hline & $+\rightarrow-$ & 1.572 & 1 & 9.450 & 4.051 & 2.469 & Yok \\
\hline \multirow{4}{*}{$\mathrm{FR} \rightarrow \mathrm{IPI}$} & $+\rightarrow+$ & $7.534 * *$ & 1 & 8.084 & 3.855 & 2.643 & Var \\
\hline & $-\rightarrow-$ & $3.062 *$ & 1 & 8.588 & 3.914 & 2.551 & Var \\
\hline & $-\rightarrow+$ & 2.329 & 1 & 8.085 & 3.962 & 2.652 & Yok \\
\hline & $+\rightarrow-$ & 0.105 & 1 & 7.876 & 3.818 & 2.606 & Yok \\
\hline \multirow{4}{*}{$\mathrm{PR} \rightarrow \mathrm{IPI}$} & $+\rightarrow+$ & 0.179 & 1 & 7.660 & 3.915 & 2.667 & Yok \\
\hline & $-\rightarrow-$ & 1.026 & 1 & 8.365 & 3.906 & 2.612 & Yok \\
\hline & $-\rightarrow+$ & $2.818^{*}$ & 1 & 8.115 & 3.920 & 2.638 & Var \\
\hline & $+\rightarrow-$ & 0.092 & 1 & 7.474 & 3.771 & 2.634 & Yok \\
\hline
\end{tabular}

Not: * ** strastyla \%10 ve \%5 seviyesindeki anlamlllı̆̆ ifade etmektedir. P, uygun gecikme uzunluğunu göstermekte ve Hatemi-J (2003) kriteriyle tespit edilen VAR modele ek olarak bir gecikme eklenmesi ile elde edilmiştir. Uygun kritik değerler 10000 bootstrap simülasyonu ile elde edilmiștir.

Tablo 7'de elde edilen Hatemi-J asimetrik nedensellik testi bulgularına göre; finansal risk değişkeninden büyümeye doğru hem pozitif hem de negatif şoklardan kaynaklanan bir nedensellik ilişkisi söz konusudur. Bir başka ifadeyle finansal risk değişkenindeki negatif şoklar büyümenin negatif şoklarının ve finansal risk değişkenindeki pozitif şoklar büyümenin pozitif şoklarının Granger nedenidir. Benzer şekilde politik risk değişkenindeki negatif şoklar büyümedeki pozitif şoklarının Granger nedenidir. Yani politik risk değişkeninde yaşanan riskteki azalmalar büyümedeki artışların Granger nedenidir.

Tablo 6 ve 7'de elde edilen bulgular tüm zaman periyodunu kapsamaktadır. Bu sonuçların geçici ya da kalıcı olup olmadığını tespit etmek amacıyla zamanla değişen simetrik ve asimetrik nedensellik analizi yapılmıştır.

\subsubsection{Ampirik Bulgular: Zamanla Değişen Simetrik Nedensellik Testi}

Kullanmış olduğumuz yöntem ekonomik, finansal ve politik risk değişkenlerinin zaman içerisinde büyüme ile ilişkisini belirlemektedir. Elde edilen bulgular aşağıda verilmektedir. 
Şekil 1. Ekonomik Risk ile Büyüme Arasındaki Nedensellik İlişkisi

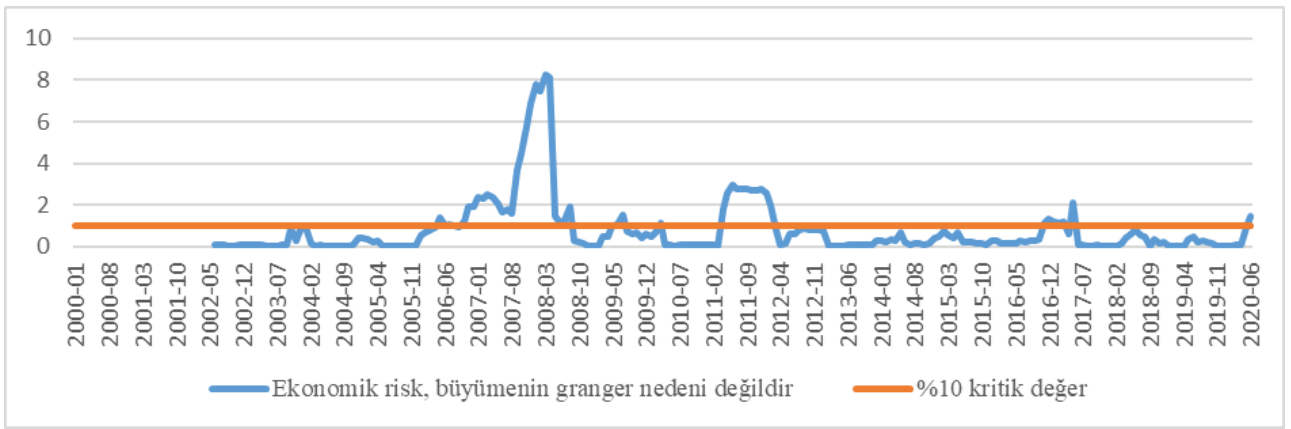

Türkiye'de ekonomik risk ile büyüme arasındaki nedensellik ilişkisi; 2003:12-2006:08, 2004:05-2008:08, 2007:01-2009:07, 2007:10-2010:03, 2008:11-2012:02, 2014:06-2017:03, 2014:12-2017:05, 2018:01-2020:06 dönemlerinde gerçekleşmiştir.

\section{Şekil 2. Finansal Risk ile Büyüme Arasındaki Nedensellik İlişkisi}

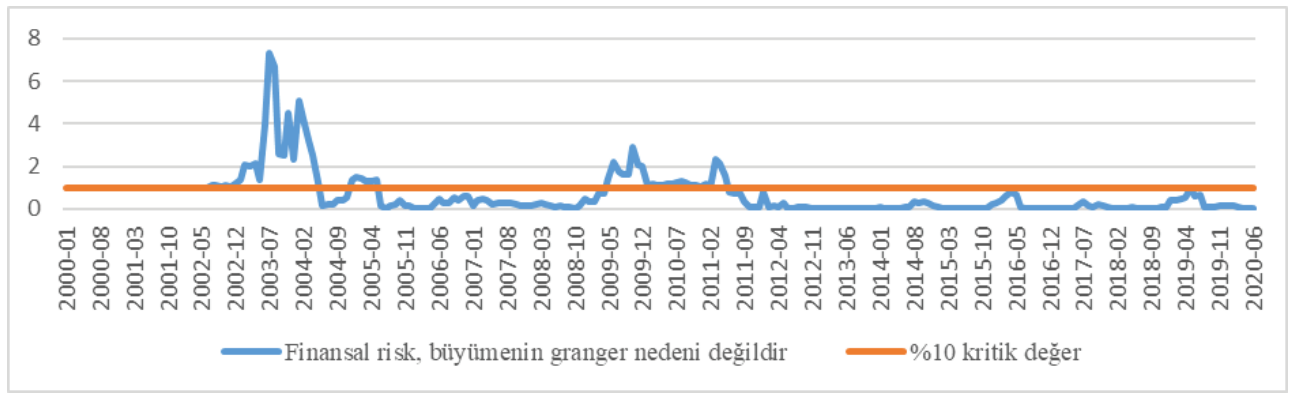

Türkiye'de finansal risk ile büyüme arasındaki nedensellik ilişkisi; 2000:02-2004:05, 2002:07-2005:05, 2006:12-2016:01, 2008:10-2011:05 dönemlerinde gerçekleşmiştir.

Şekil 3. Politik Risk ile Büyüme Arasındaki Nedensellik İlişsisi

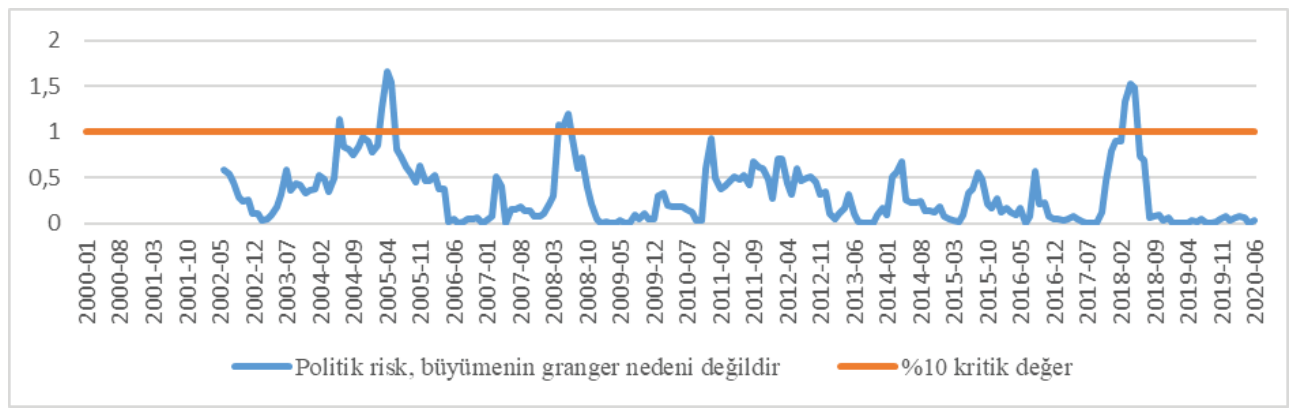

Türkiye'de politik risk ile büyüme arasındaki nedensellik ilişkisi; 2002:01-2004:06, 2002:10-2005:05, 2005:11-2008:06, 2015:10-2018:05 tarihleri arasında gerçekleşmiştir. 
Nedensellik ilişkisinin görüldüğü dönemlerde gerek ekonomik ve finansal gerekse politik pek çok olayın yaşandığını söylemek mümkündür. Ancak bu olayların olumlu veya olumsuz etkisini değerlendirebilmek için zamanla değişen asimetrik nedensellik testi yapılmıştır. Çünkü asimetrik nedensellik testi sonucunda olayların olumlu veya olumsuz etkisi görülmektedir.

\subsubsection{Ampirik Bulgular: Zamanla Değişen Asimetrik Nedensellik Testi}

Zamanla değişen asimetrik nedensellik testi ekonomik, finansal ve politik risk karşısında büyümede yaşanan gelişmeleri pozitif (büyümede artış) ve negatif (büyümede azalış) şok olarak saptama imkânı vermektedir.

Şekil 4. Ekonomik Risk ve Büyüme: Pozitif-Negatif Şoklar

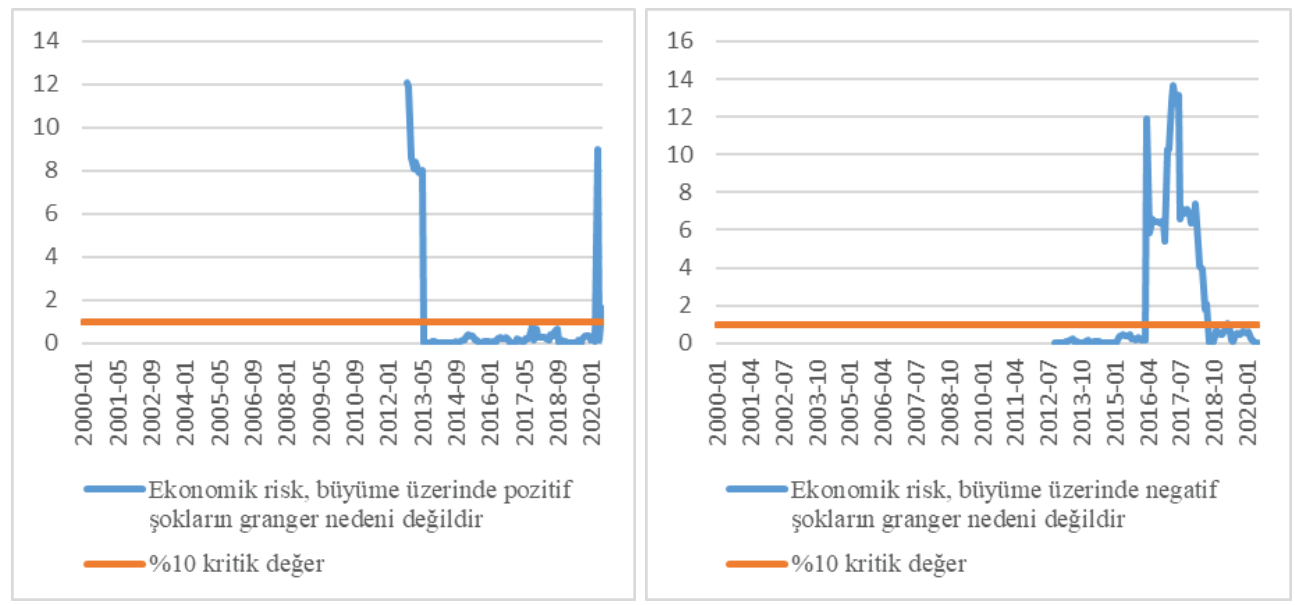

Şekilde pozitif şoklar (sol) ve negatif şoklar (sağ) yer almaktadır. Buna göre; 2010:052013:05, 2017:11-2020:04, 2018:01-2020:06 tarihleri arasında ekonomik riskin büyümeyi pozitif etkilediği; 2013:11-2018:07, 2016:11-2019:04 tarihleri arasında ise negatif etkilediği görülmektedir. Ekonomik riskin büyümeyi pozitif etkilediği dönemlerde (2010-2013, 2017 2020), temel makroekonomik göstergelerde; kişi başına GSYH (2010-2013 artış), enflasyon oranı (2010-2012 azalış), bütçe dengesi/GSYH (2010-2011, 2012-2013, 2014-2015 azalış), dış borçlar (2014-2015, 2017-2020 azalış) ve cari denge/GSYH (2011-2012, 2013-2016 azalış) iyileşmeler yaşanmıştır. Ekonomik riskin büyümeyi negatif etkilediği dönemlerde (2013-2019) ise kişi başına GSYH (2013-2019 azalış), enflasyon oranı (2013-2019 artış), bütçe dengesi/GSYH (2013-2014, 2015-2019 artış), dış borçlar (2010-2014, 2016-2017 artış) ve cari denge/GSYH (2012-2013, 2016-2019 artış) ekonomide bozulmalar yaşanmıştır. Özetle ekonomik riskin büyümeyi pozitif ve negatif etkilediği dönemlerle ülkenin makroekonomik göstergelerinde yaşanan gelişmeler birbirini desteklemektedir ${ }^{5}$.

\footnotetext{
${ }^{5}$ Ekonomik ve finansal yorumlar TÜİK, Hazine ve Maliye Bakanlığı ve TCMB'nin yayınladığı resmi veriler kullanılarak yapılmıştır.
} 


\section{Şekil 5. Finansal Risk ve Büyüme: Pozitif-Negatif Şoklar}
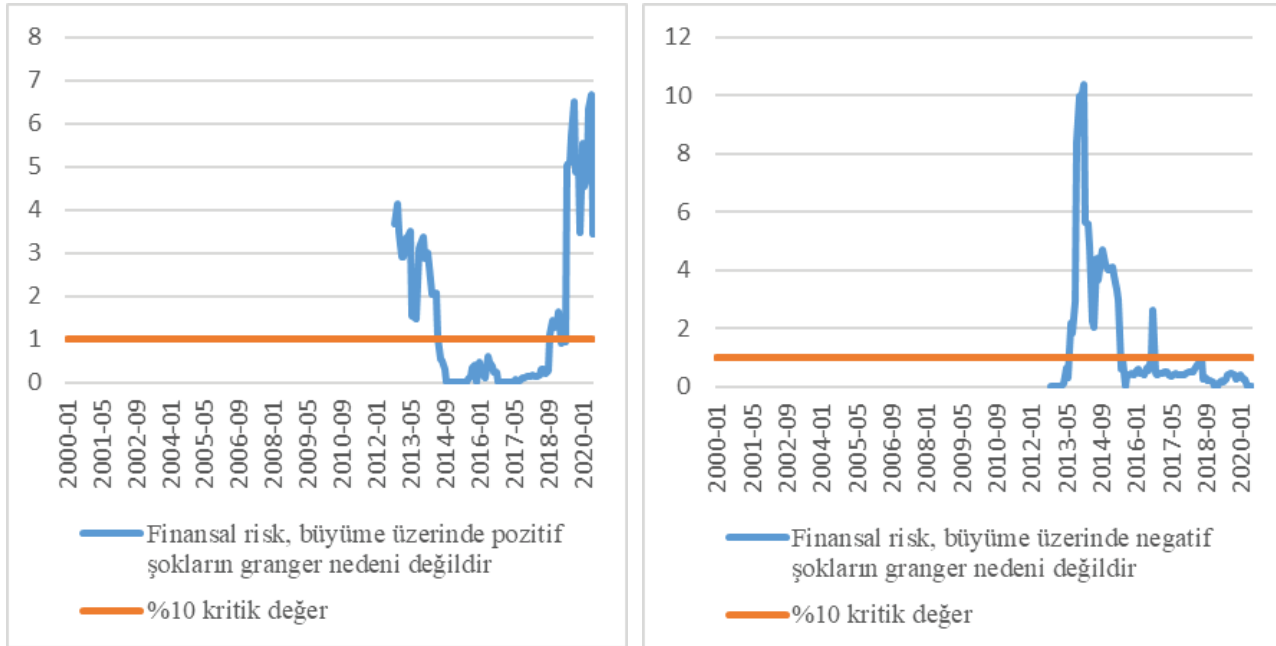

Şekilde pozitif şoklar (sol) ve negatif şoklar (sağ) yer almaktadır. Buna göre; 2010:052014:06, 2016:05-2019:02, 2016:11-2019:04, 2017:01-2020:06 tarihleri arasinda finansal riskin büyümeyi pozitif etkilediği; 2011:02-2015:05, 2014:04-2016:09, 2016:02-2018:07 tarihleri arasında ise negatif etkilediği görülmektedir. Ekonomik istikrardaki bir bozulma anında finansal sistemi etkileyebildiğinden, yukarıda ekonomik risk kısmında bahsedilen makroekonomik göstergelerdeki gelişmeler finansal risk için de geçerlidir.

Şekil 6. Politik Risk ve Büyüme: Pozitif-Negatif Şoklar
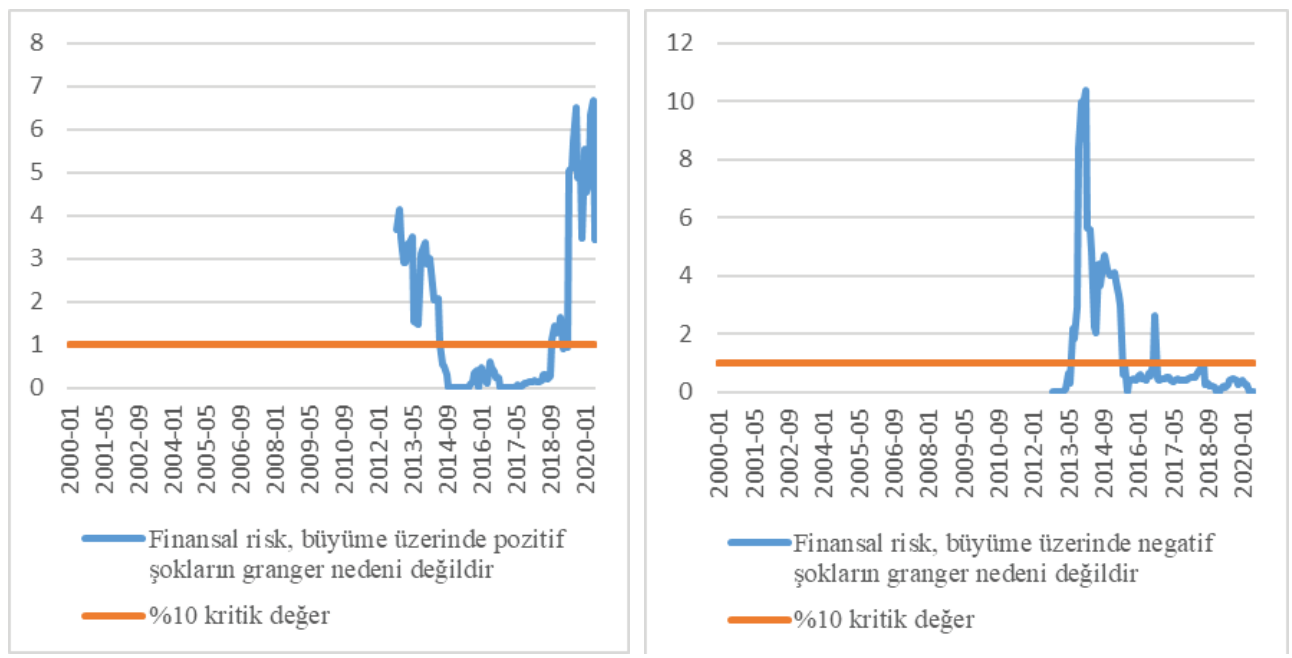
Şekilde pozitif şoklar (sol) ve negatif şoklar (sağ) yer almaktadır. Buna göre; politik risk büyümeyi pozitif etkilemezken, 2011:05-2013:10, 2012:10-2015:03, 2013:01-2015:07, 2013:11-2016:10, 2014:08-2017:01 tarihleri arasında negatif etkilediği görülmektedir. Bu negatif ilişki söz konusu dönemlerde politik riskin yüksek olduğunu ifade etmektedir. Bu bağlamda Türkiye'de önemli bazı politik olayların yaşandığı görülmektedir. 2011 yılında genel seçimler (hükümet istikrarı), 2012 yılında ABD başkanlık seçimleri (dış faktörler), 2013 yılında başlayan Gezi olayları, yolsuzluk ve rüşvet operasyonları (iç çatışma, sivil kargaşa, yolsuzluk, hukuk ve düzen), 2014 yılında yerel seçimler, Cumhurbaşkanlığ seçimleri (hükümet istikrarı, sosyoekonomik koşullar, demokratik hesap verilebilirlik), 2015 yılında genel seçimler, kabinenin kurulamaması, artan terör olayları, seçimlerin tekrar edilmesi, Rus savaş uçağının düşürülmesi (hükümet istikrarı, terörizm, iç ve dış çatışma), 2016 yılında Sultanahmet ve İstiklal caddesi bombalı saldırıları, 15 Temmuz darbe girişimi, Suriye Fırat kalkanı operasyonu, Rusya’nın Büyükelçisi Karlov’un öldürülmesi (terörizm, ordunun siyasetteki rolü, iç ve dış çatışma), 2017 yılında yılbaşı gecesi Reina'ya saldırı, Hollanda ile diplomasi krizi, Cumhurbaşkanlığı sistemi halk oylaması (terörizm, dış faktörler, hükümet istikrarı) gibi. Söz konusu olaylar sonucunda en çok hükümet istikrarı, iç çatışma ve terör başlıkları ile karşılaşılmaktadır. Bu başlıklar politik risk oranını belirleyen önemli değişkenlerdir 6 .

\section{Sonuç}

Neden bazı ülkeler hızla gelişirken bazı ülkeler hızla gelişememiş ya da daha yavaş gelişmişlerdir? Neden ülkeler arasında gelişmişlik farklılıkları söz konusudur? Bu sorulara cevap aramak her daim iktisatçıların gündeminde yer almıştır. Bu çalışmada gelişmiş ülke konumuna gelmek için çaba gösteren ve gelişmekte olan ülke statüsünde olan Türkiye'nin ekonomik, finansal ve politik risk oranlarının büyüme üzerindeki etkisi 2000:01-2020:06 dönemi için analiz edilmiştir. Bunun için Toda-Yamamoto nedensellik testi, Bootstrap TodaYamamoto nedensellik testi ve zamanla değişen simetrik ve asimetrik nedensellik testleri kullanılmıştır.

Elde edilen bulgulara göre; Toda-Yamamoto nedensellik testi finansal risk değişkeninden ekonomik büyümeye, ekonomik risk değişkeninden finansal risk değişkenine ve ekonomik risk değişkeninden politik risk değişkenine doğru nedensellik ilişkisi olduğunu göstermektedir.

Bootstrap Toda-Yamamoto nedensellik testi bulgularına göre finansal risk değişkeninden ekonomik büyümeye doğru bir nedensellik ilişkisi vardır. Bootstrap Toda-Yamamoto asimetrik nedensellik testi bulgularına göre finansal risk değişkeninden kaynaklanan pozitif şoka

\footnotetext{
${ }^{6}$ Politik olaylar Hürriyet, Milliyet, Sözcü, Sabah, Radikal, Dünya Gazetesi, BBC ve Aljazeera.com.tr., NTV.com.tr. adreslerinde yer alan haberlere göre yorumlanmıştır.
} 
ekonomik büyümenin pozitif tepki verdiği, aynı şekilde negatif şoka karşılık da ekonomik büyümenin negatif tepki verdiği görülmektedir. Bir diğer değişken olan politik risk değişkeninde meydana gelen negatif bir şok ekonomik büyüme üzerine pozitif bir şoka yol açmaktadır. Zamanla değişen simetrik nedensellik testi bulgularına göre; ekonomik risk değişkeninden ekonomik büyümeye doğru nedensellik ilişkisinin olduğu dönemler genel hatlarıyla; 2003:12-2012:02, 2014:06-2017:05, 2018:01-2020:06 dönemlerinde; finansal risk değişkeninde 2000:02-2011:05 döneminde ve politik risk değişkeninde ise 2002:01-2018:05 dönemindedir. Zamanla değişen asimetrik nedensellik testi bulgularına göre; ekonomik risk değişkeninde meydana gelen negatif şokların ekonomik büyümeyi 2010:05-2020:06 döneminde pozitif, ekonomik risk değişkeninde meydana gelen pozitif şokların ise ekonomik büyümeyi 2013:11-2019:04 döneminde negatif etkilediği görülmektedir. Bu şoklar, finansal risk değişkeninde 2010:05-2020:06 döneminde pozitif; 2011:02-2018:07 döneminde ise negatif yönde etki yaratmaktadır. Dolayısıyla ekonomik ve finansal risk değişkenlerinde meydana gelen şokların ekonomik büyüme üzerine etkileri benzer dönemlerde gerçekleşmiştir. $\mathrm{Bu}$ durum ekonomik ve finansal risklerin birbirini desteklediği teorik görüşü desteklemektedir. Ancak söz konusu dönemde politik risk değişkeninden ekonomik büyüme doğru pozitif bir şokun olmadığı, buna karşın 2011:05-2017:01 döneminde politik risk oranında artışların olduğu ve ekonomik büyümeyi negatif etkilediği görülmektedir.

Risk türlerinin ekonomik büyüme üzerine etkisi genel olarak değerlendirildiğinde Türkiye'de bütün bu risk türlerinde yaşanan iyileşme veya bozulmaların ekonomik büyüme üzerine olumlu veya olumsuz etkileri söz konusudur. Ayrıca son dönemlerde ekonomik ve finansal risklerin ekonomik büyüme üzerindeki etkisi politik riske göre daha fazla olduğu görülmektedir. Bu bilgiler ışığında ekonomik ve finansal riskleri azaltıcı politika ve tedbirlerin alınmasının gerekli olduğu söylenebilir. Bu bağlamda Türkiye'de son dönemlerde özellikle 2012 sonrasında bozulmaların yaşandığı; kişi başına GSYH, döviz kuru, bütçe dengesi, enflasyon oranı, cari denge, dış borçlar gibi göstergelerde iyileştirici tedbirlerin alınması gerektiğini göstermektedir.

Hakem Değerlendirmesi: Dış bağımsız.

Yazar Katkıları: Çalışma Konsepti/Tasarım- E.S.Y., C.D., M.I.Ö.; Veri Toplama- E.S.Y., C.D.; Veri Analizi/Yorumlama- E.S.Y., C.D.; Yazı Taslağı- E.S.Y., C.D., M.I.Ö.; İçeriğin Eleştirel İncelemesi- E.S.Y., C.D., M.I.Ö.; Son Onay ve Sorumluluk- E.S.Y., C.D., M.I.Ö. Çıkar Çatışması: Yazarlar çıkar çatışması beyan etmemişlerdir.

Finansal Destek: Yazarlar finansal destek beyan etmemişlerdir.

Peer-review: Externally peer-reviewed.

Author Contributions: Conception/Design of Study- E.S.Y., C.D., M.I.Ö.; Data Acquisition- E.S.Y., C.D.; Data Analysis/InterpretationE.S.Y., C.D.; Drafting Manuscript- E.S.Y., C.D., M.I.Ö.; Critical Revision of Manuscript- E.S.Y., C.D., M.I.Ö.; Final Approval and Accountability- E.S.Y., C.D., M.I.Ö.

Conflict of Interest: The author has no conflict of interest to declare.

Grant Support: Authors declared no financial support. 


\section{Kaynakça/References}

Acemoğlu, D. (2012). Introduction to economic growth. Journal of Economic Theory, 147, 545-550.

Aisen, A., \& Veiga, F. J. (2013). How does political instability affect economic growth?. European Journal of Political Economy, 29, 151-167.

Akimov, A., Wijeweraa, A., \& Dollery, B. (2009). Financial development and economic growth: Evidence from transiton economies. Applied Financial Economics, 19(12), 999-1008.

Alper, A. E. (2018). BRICS-T ülkelerinde politik istikrar ve ekonomik performans ilişkisi üzerine bir analiz. Business and Economics Research Journal 9(1), 49-56.

Alesina, A., Özler, S., Roubini, N., \& Swagel, P. (1996). Political stability and economic growth. Journal of Economic Growth, 1(2), 189-211.

Arslan, Ü. (2011). Siyasi istikrarsızlık ve ekonomik performans: Türkiye örneği. Ege Akademik Bakış, 11(1), 73-80.

Asteriou, D., \& Price, S. (2001). Political instability and economic growth: UK time series evidence. Scottish Journal of Political Economy, 48(4), 383-399.

Baklouti, N. \& Boujelbene, Y. (2018). An econometric study of the role of the political stability on the relationship between democracy and economic growth. Panoeconomicus, 67(2), 187-206.

Barro, R. J. (1995). Inflation and economic growth. Bank of England Quarterly Bulletin, 35(2), 407-443.

Berber, M., \& Artan, S. (2004). Enflasyon ve ekonomik büyüme ilişkisi: Türkiye örneği. Turkish Economic Association Discussion Paper, 21, 1-14.

Belkhir, M., Grira, J., Hassan, M. K., \& Soumaré, I. (2018). Islamic banks and political risk: International evidence. Quarterly Review of Economics and Finance, 74, 39-55.

Beşkaya, A., \& Koç, A. (2006). Ekonomik büyüme ve kalkınmada ekonomik özgürlüklerin rolü ve önemi. Liberal Düşünce, Say1 43, 1-30.

Brooks, C., \& Hinich, M. (1998). Episodic nonstationarity in exchange rates. Appl. Econ. Lett., 5(11), 719-722.

Brückner, M., \& Gradstein, M. (2015). Income growth, ethnic polarization, and political risk: Evidence from international oil price shocks. Journal of Comparative Economics, 43(3), 575-594.

Calderon, C., \& Liu, L. (2003). The direction of causality between financial development and economic growth. Journal of Development Economics, 72(1), 321-334.

Campos, N. F., \& Nugent, J. B. (2002). Who is afraid of political instability?. Journal of Development Economics, $67(1), 157-172$.

Caporale, M. C., Rault, C., \& Sova, A. R. (2009). Financial development and economic growth: evidence from ten new EU members. Discussion Papers, No: 904, 1-39.

Caspi, I. (2017). Rtadf: testing for bubbles with eviews. Journal of Statistical Software, 81(1), 1-16.

Chen, B., \& Feng, Y. (1996). Some political determinants of economic growth: theory and empirical implications. European Journal of Political Economy, 12(4), 609-627

Christopoulos, D. K., \& Tsionas, E. G. (2004). Financial development and economic growth: evidence from panel unit root and cointegration tests. Journal of Development Economics, 73(1), 55-74.

Çela, A., \& Hysa, E. (2021). Impact of political instability on economic growth in CEE countries. Ekonomika Regiona [Economy of region], 17(2), 582-592.

Das, A., \& Loxley J. (2015). Non-linear relationship between inflation and growth in developing countries. Economic \& Political Weekly, 1(37), 59-64.

Demez, S., Kızılkaya, F., \& Turan, İ. (2019). NIC ülkelerinde politik istikrar ve ekonomik büyüme ilişkisi. Siirt Üniversitesi Sosyal Bilimler Enstitüsü Dergisi, Sayı: 14, 485-499. 
Demetriades, Panicos O., \& Hussein, Khaled A. (1996). Does financial development cause economic growth? Timeseries evidence from 16 countries. Journal of Development Economics, 51(2), 387-411.

Demirgil, H. (2011). Politik istikrarsızlık, belirsizlik ve makroekonomi: Türkiye örneği (1970-2006). Marmara Üniversitesi İ̈BF Dergisi, 16(2), 123-144.

Dickey, D. A., \& Fuller, W. A. (1981). Likelihood ratio statistics for autoregressive time series with a unit root. Econometrica, 49(4), 1057-1072.

Dudian, M., \& Popa, R. A. (2013). Financial development and economic growth in central and eastern europe. Theoretical and Applied Economics, 20(8/585), 59-68.

Erdoğan, S., Gedikli, A., \& Kırca, M. (2019). A note on time-varying causality between natural gas consumption and economic growth in Turkey. Resources Policy, 64, 1-7.

Feng, Y. (2001). Political Freedom, Political instability and policy uncertainty: A study of political institutions and private investment in developing countries. International Studies Quarterly, 45, 271-294.

Fischer, Stanley. (1993). The role of macroeconomic factors in growth. Journal of Monetary Economics, 32(3), 485-512.

Granger, C., \& Yoon, G. (2002). Hidden cointegration. Department of Economics Working Paper University of California, No:2002-02.

Gregory, R. P. (2019). Financial openness and entrepreneurship. Research in International Business and Finance, $48,48-58$

Gujarati, D. N. (1995). Basic econometrics (Third edit). McGraw Hill Com. Inc.

Gurgul, H., \& Lach, L. (2013). Political instability and economic growth: evidence from two decades of transition in CEE. Communist and Post-Communist Studies, 46(2), 189-202.

Gür, T. H., \& Akbulut, H. (2012). Gelişmekte olan ülkelerde politik istikrarın ekonomik büyüme üzerine etkisi. Sosyoekonomi, 282-300.

Hatemi-J, A. (2003). A new method to choose optimal lag order in stable and unstable VAR models. Applied Economics Letters, 10(3), 135-137.

Hatemi-J, A. (2012). Asymmetric causality tests with an application. Empirical Economics, 43(1), 447-456.

Hacker, R., \& Hatemi-J, A. (2006). Tests for causality between integrated variables using asymptotic and bootstrap distributions: Theory and application. Appl. Econ., 38(13), 1489-1500.

Howell, L. D., \& Chaddick, B. (1994). Models of political risk for foreign investment and trade- an assessment of three approaches. The Columbia Journal of World Business, 70-91.

ICRG (2020). International country risk guide political risk rating system, Political Risk Services Group.

Jones, C. I. (2017). Íktisadi büyümeye giriş. (Sanlı Ateş;İsmail Tuncer,Çev.) İstanbul:Literatür Yayıncılık

Jong-A-Pin, R. (2009). On the measurement of political instability and its impact on economic growth. European Journal of Political Economy, 25, 15-29.

Karamelikli, H., \& Bayar, Y., (2016). Makroekonomik ve finansal istikrarın ekonomik büyüme üzerindeki etkisi: Türkiye örneği. Uluslararası Yönetim Íktisat ve Işsletme Dergisi, ICAFR 16 Özel Sayısı, 225-236.

Kartal, G., \& Öztürk, S. (2017). Türkiye’de politik istikrarsızlık ve ekonomik büyüme ilişkisi. Ömer Halisdemir Üniversitesi İktisadi Ve İdari Bilimler Fakültesi Dergisi, 10(4), 250-270

Kamacı, A. (2019). Politik istikrarsızlık-ekonomik büyüme ilişkisi: 20 OECD ülkesi için panel veri analizi. Ticari Bilimler Fakültesi Dergisi, 3(2), 75-85.

Kamacı, A., (2016). Dış borçların ekonomik büyüme ve enflasyon üzerine etkileri: Panel eşbütünleşme ve panel nedensellik analizi. International Journal of Cultural and Social Studies (IntJCSS), Volume 2 (Special Issue 1), $165-175$. 
Kanca, O.C. (2012). Türkiye'de işsizlik ve iktisadi büyüme arasındaki nedenselliğin ampirik bir analizi. Ç.Ü. Sosyal Bilimler Enstitüsü Dergisi, 21(2), 1-18.

Kenourgios, D. \& A. Samitas (2007). Financial development and economic growth in a transition economy: Evidence for Poland. Journal of Financial Decision Making, 3(1), 35-48.

Kırca, M., \& Yıldız, Ü. (2020). Türkiye için kredi risk primi (cds) ve ekonomik büyüme arasındaki zamanla değişen nedensellik ilişkileri. Internatıonal Journal Of Afro-Eurasıan Research (IJAR), 5(10), 17-24.

Kızılkaya, O. \& Sofuoğlu, E. (2016). BRIC-T ülkelerinde politik risk ile ekonomik büyüme arasındaki ilişki: heterojen panel nedensellik analizi. Uluslararası Ekonomi Konferansı, Türkiye Ekonomi Kurumu, UEK-TEK 2016, 223-232.

Kutlu, S. \& Yurttagüler, İ. M. (2016). Türkiye'de dış borç ve ekonomik büyüme ilişkisi: 1998-2014 dönemi için bir nedensellik analizi. Marmara Üniversitesi İktisadi ve İdari Bilimler Dergisi, 38(1), 229-248.

Muscatelli, V.A. \& Tirelli P. (2001). Unemployment and growth: some empirical evidence from structural time series models. Journal of Applied Econometrics, 33, 1083-1088.

Nazeer, A. M. \& Masih, M. (2017). Impact of political instability on foreign direct investment and economic growth: evidence from Malaysia. MPRA Paper No. 79418 https://mpra.ub.uni-muenchen.de/79418/

Okafor, G. (2015). The impact of political instability on the economic growth of ecowas member countries. Defence and Peace Economics, 28(2), 208-229

Parlakyıldız, F. M. (2015). Makro ekonomik ve politik istikrarsızlı̆̆ın ekonomik performans üzerine etkisi: Latin Amerika örneği. Çukurova Üniversitesi İ̈BF Dergisi, 19(2), 1-11.

Pattillo, C. (2011). External debt and growth. Review of Economics and Institutions, 2(3), Fall, Article 2, 1-30.

Phillips, P. C. B., \& Perron, P. (1988). Testing For A Unit Root İn Time Series Regression. Biometrika, 75(2), 335346.

Pasha, S. (2020). The impact of political instability on economic growth: the case of Guyana. MPRA Paper No. 103145, https://mpra.ub.uni-muenchen.de/103145/1/MPRA_paper_103145.pdf

Radu, M. (2015). Political stability - a condition for sustainable growth in Romania?. Procedia Economics and Finance, 30, 751-757.

Soytaş, U., \& Küçükkaya, E. (2011). Economic growth and financial development in Turkey: New evidence. Applied Economics Letters, 18(6), 595-600.

Şanlısoy, S., \& Kök, R. (2010). Politik istikrarsızlık ekonomik büyüme ilişkisi: Türkiye örneği (1987-2006). Dokuz Eylül Üniversitesi İktisadi ve İdari Bilimler Fakültesi Dergisi, 25(1), 101-125

Tang, C.F. \& Abosedra, S. (2014). The impacts of tourism,energy consumption and political instability on economic growth in the MENA countries. Energy Policy, 68, 458-464.

Toda, H., \& Yamamoto, T. (1995). Statistical inference in vector autoregressions with possibly integrated processes. J. Econom., 66(1), 225-250.

Uçak, S. (2017). Cari denge ve ekonomik büyüme ilişkisi: Türkiye analizi, MCBÜ Sosyal Bilimler Dergisi 15(2), 107-140.

Üçler, G. (2017). Doğrudan yabancı yatırımlar için kurumların önemi: Gelişmekte olan ülkeler üzerine ekonometrik bir analiz. Finans Politik \& Ekonomik Yorumlar, 54(627), 73-85.

Yalçınkaya, Ö., \& Kaya, V. (2017). Politik istikrarı/istikrarsızlı̆̆ın ekonomik büyüme üzerindeki etkileri: dünyanın en büyük ilk yirmi ekonomisi üzerinde bir uygulama (1996-2015). Uluslararası Yönetim İktisat ve Işsletme Dergisi, 13(2): 277-298.

Yapraklı, S., \& Güngör, B. (2007). Ülke riskinin hisse senedi fiyatlarına etkisi: IMKB 100 endeksi üzerine bir araştırma. Ankara Üniversitesi SBF Dergisi, 62(2), 199-2018. 
Yılanc1, V., \& Bozoklu, Ş. (2014). Price and trade volume relationship in Turkish capital market: Time-varying asymmetric causality analysis. Ege Akademik Bakis (Ege Acad.Rev.), 14(2), 211-220.

Younis, M., Lin, XX., Sharahili, Y., \& Selvarathinam, S. (2008). Political stability and economic growth in Asia. American Journal of Applied Sciences 5(3):203- 208.

Zouhaier, H., \& Kefi, M.K. (2012). Interaction between political instability and investment. Journal Of Economics And International Finance, 4(2):49-54. 